\title{
AEROMAGNETIC MAP OF PART OF THE DENNIS QUADRANGLE, BARNSTABLE COUNTY, MASSACHUSETTS
}

\author{
GEOPHYSICAL INVESTIGATIONS \\ MAP GP-806
}

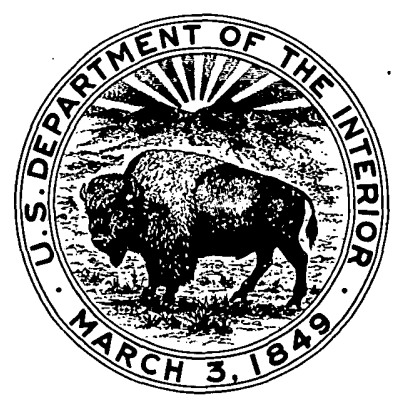

